\title{
Felt Manufacture
}

Felt - made from wool, fur, or hair fibers matted together-is one of the oldest types of fabric used in human civilization. Due to natural crimp and surface scales, certain fibers interlock and compact when they are subjected to moisture, heat, agitation, and pressure, thereby forming a dense fabric without the need for spinning, knitting, or weaving.

Felt caps from the Bronze Age (circa 3500 B.C.) have been excavated in Europe. In 1000 B.C., Homer wrote that the Greeks used felt in capes, slippers, and pads. In the ruins of Pompeii, workshops for the manufacture of felt hats and gloves have been found. Archaeological excavations of Scythian royal graves in Siberia have uncovered decorative rugs and other articles made of felt with applique patterns; these items date from the fifth to the third century B.C. The Scythians also lined their floors and walls with felt.

Many nomadic tribes in Central Asia still produce felt for shelter and clothing, following techniques handed down for thousands of years: washing wool or fur, spreading it out, moistening it with water or whey, and beating it with sticks. After the fall of the Roman Empire, however, the art of felting was lost to Europe until it was rediscovered in the Near East during the Crusades (circa A.D. 1100).

Although most felt at that time was black, by A.D. 1300 dyed felts began to be made. By the end of the 14th century, beaver hair had become a predominant material for felting, especially in the manufacture of hats. In 1386, Chaucer described a "Flaundrish [Flanders] bever hat," and in 1449 Charles VII of France made his public entry into the city of Rouen wearing a large black beaver hat crowned with a tuft of feathers and lined with red velvet. Such hats were, however, enormously expensive.

In 1534, the French explorer Jacques Cartier reached the Gulf of St. Lawrence in North America and discovered a wealth of beavers, along with Algonquin Indians eager to trade the pelts. Shortly thereafter, French hatters began to pro- duce great quantities of cheap, fine-quality felt hats made from North American beaver fur. Toward the end of the 16th century, merchants and artisans began to adopt the style of beaver-felt hats. As the demand for beaver pelts increased, Native American tribes began to war on each other for the rights to barter furs with the Europeans.

Other than beaver, the most important fibers used in felt manufacture are wool (short-staple) and hair from rabbits, coney hares, muskrats, and similar animals. Resourceful people have also made felt from cow, goat, and camel hair. Since the industrial revolution and the mechanization of the textile industry, felts have also been made from mill wastes, reprocessed wool, and cotton fibers. Massproduction of felt was made possible in the $18 \mathrm{th}$ century with the introduction of the automatic wool-carding machine.

In the felting process, raw wool or animal skins are scoured and treated to remove tar, dirt, and vegetable matter such as burrs. For wool, the strands are carded (a combing process that makes the fibers parallel), and the short fibers (less than about $4 \mathrm{~cm}$ ) are separated out for use in felting.

On a fur pelt, the long, coarse guard hairs are removed by pulling and shearing, which leaves only the soft underfur. The felting properties of fur fibers are improved by "carroting," or treatment with chemical compounds, which kinks the fibers and makes them form a stronger felting mat. Carroting is named for the color of the nitrate of mercury originally used in the process, particularly in the hatmaking industry. (Fumes from the nitrate of mercury also caused severe harm to workers, resulting in the occupational disease known as "hatter's shakes" and the phrase "mad as a hatter." The use of nitrate of mercury was discontinued in the 1940s.)

After carroting, fur fibers are graded according to whether they came from the cheek, back, center, flank or side, then blended to create a mixture with the desired quality and properties. For hatmak- ing, the blended fur or wool fibers are divided into small packets, each containing about enough material for a single hat. In modern manufacturing methods, an exhaust fan blows the loose fibers onto a whirling cone of copper meshabout three feet high and six feet around-distributing the blend evenly until the cone is completely covered. This giant, thin conical coating of fur or wool is immersed in warm water or a dilute sulfuric acid solution and then pressed to shrink it down to the size of a hat.

Felts do not require an adhesive to hold the fiber mat together; however, to stiffen certain felts for hats and other special uses, the felt form can be dipped into a weak solution of shellac. The amount of shellac varies, depending on the stiffness required for the finished article. The crown of the hat is then pulled into shape by a mechanical stretcher, a machine with metal fingers. The hat is given its finished shape on a wooden hat block, where it is steamed and ironed. The brim of the hat is curled with heated metal flanges.

Certain distinctive styles of felt hats require special treatments. The British policemen's helmet and the bowler hat, or derby, go through special finishing processes such as waterproofing and heavy coatings of shellac. Gray toppers are made of a special blend of fur. Felt hats, in general, can be treated with special finishes to make the material flameproof or mothproof.

Modern felt can be made in many weights, ranging from 3 ounces to 65 pounds per square yard (100 to 3,600 $\left.\mathrm{g} / \mathrm{m}^{2}\right)$ and in thicknesses from $1 / 32$ to 3 inches $(0.08$ to $7.6 \mathrm{~cm})$. Wool can produce a felting mat even when mixed with "nonfelting" synthetic or natural fibers. The felting power of wool is so strong that as little as $10 \%$ in a blend with nonfelting fibers will produce a felt.

In addition to its wide use in the hat industry, more than 150 types of felt are used for garments, drapery, furniture padding, and slippers. Industrial uses include packaging, thermal insulation, sealing, soundproofing, shock damping, and polishing.

KEVIN J. ANDERSON

\section{Fall Meeting Registration}

\author{
To register for the 1993 MRS Fall Meeting...simply photocopy the registration form \\ on page 67 , fill in the information, and return it to MRS.
}

